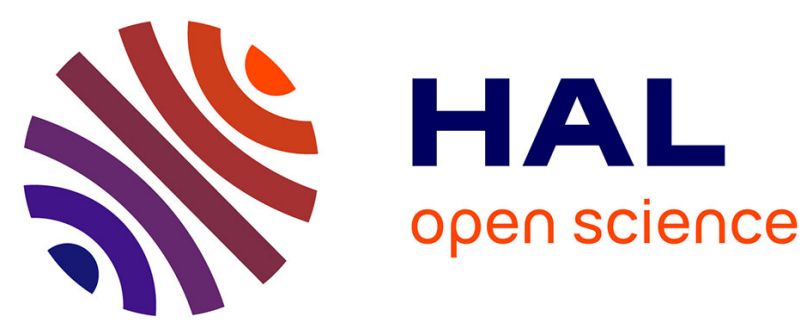

\title{
Kawasaki disease in adults: observations in France and literature review Short title: Kawasaki disease in adults in France
}

Jean-Baptiste Fraison, Pascal Seve, Claire Dauphin, Alfred Mahr, Emeline Gomard-Mennesson, Loig Varron, Gregory Pugnet, Cédric Landron, Pascal Roblot, Eric Oziol, et al.

\section{To cite this version:}

Jean-Baptiste Fraison, Pascal Seve, Claire Dauphin, Alfred Mahr, Emeline Gomard-Mennesson, et al.. Kawasaki disease in adults: observations in France and literature review Short title: Kawasaki disease in adults in France. Autoimmunity Reviews, 2015, In press. 10.1016/j.autrev.2015.11.010 . hal-01240471

HAL Id: hal-01240471

https://hal-univ-rennes1.archives-ouvertes.fr/hal-01240471

Submitted on 17 Dec 2015

HAL is a multi-disciplinary open access archive for the deposit and dissemination of scientific research documents, whether they are published or not. The documents may come from teaching and research institutions in France or abroad, or from public or private research centers.
L'archive ouverte pluridisciplinaire HAL, est destinée au dépôt et à la diffusion de documents scientifiques de niveau recherche, publiés ou non, émanant des établissements d'enseignement et de recherche français ou étrangers, des laboratoires publics ou privés. 


\title{
Kawasaki disease in adults: observations in France and literature review
}

\section{Authors}

Jean-Baptiste Fraison (MD) ${ }^{1}$; Pascal Sève (MD, PhD) ${ }^{2}$; Claire Dauphin (MD) ${ }^{3}$; Alfred Mahr $(\mathrm{MD}, \mathrm{PhD})^{1}$, Emeline Gomard-Mennesson (MD) ${ }^{4}$; Loig Varron (MD) ${ }^{5}$; Gregory Pugnet (MD, $\mathrm{PhD})^{6}$; Cédric Landron $(\mathrm{MD})^{7}$; Pascal Roblot $(\mathrm{MD}, \mathrm{PhD})^{7}$; Eric Oziol (MD) ${ }^{4}$; Gihane Chalhoub (MD) ${ }^{8}$; Jean-Marc Galempoix (MD) ${ }^{9}$; Sébastien Humbert (MD) ${ }^{10}$; Philippe Humbert (MD, PhD) $)^{11}$; Emilie Sbidian (MD) ${ }^{12}$; Florent Grange (MD, PhD) ${ }^{13}$; Olivier Bayrou $(\mathrm{MD})^{14}$; Pascal Cathebras (MD) ${ }^{15}$; Philippe Morlat (MD, PhD $)^{16}$; Olivier Epaulard (MD, $\mathrm{PhD})^{17}$; Patricia Pavese (MD) ${ }^{17}$; Thi Huong Du Boutin (MD) ${ }^{18}$; Abdelkader Zoulim (MD) ${ }^{19}$; Katia Stankovic (MD) ${ }^{20}$; Hervé Bachelez (MD) ${ }^{21}$; Amar Smail (MD) ${ }^{22}$; C. Bachmeyer $(\mathrm{MD})^{23}$; Brigitte Granel (MD, PhD) ${ }^{24}$; Jacques Serratrice (MD) ${ }^{24}$; Graziella Brinchault (MD) $)^{25}$, Arsène Mekinian (MD) ${ }^{26}$; Nathalie Costedoat-Chalumeau (MD, PhD $)^{27}$; Anne BourgaritDurand $(\mathrm{MD}, \mathrm{PhD})^{28}$; Xavier Puéchal $(\mathrm{MD}, \mathrm{PhD})^{27}$; Loïc Guillevin (MD) ${ }^{27}$; Maryam Piram $(\mathrm{MD})^{29}$; Isabelle Koné-Paut $(\mathrm{MD}, \mathrm{PhD})^{29^{*}}$; Olivier Fain $(\mathrm{MD})^{26^{*}}$ on behalf of the CRI and the French Vasculitis Study Group ${ }^{27}$

\section{* Two last authors}

\author{
Affiliations \\ 1: Service de Médecine Interne, Hôpital Saint Louis, AP HP, Université Diderot, France \\ 2: Service de Médecine Interne, Hôpital de la Croix Rousse, Centre Hospitalier Universitaire de Lyon, Université de Lyon, France \\ 3: Service de Cardiologie, Hôpital Gabriel Montpied, Université de Clermont-Ferrand, France \\ 4: Service de Médecine Interne, Centre Hospitalier de Béziers, France \\ 5: Service de Médecine Interne, Centre Hospitalier de Montélimar, France \\ 6: Service de Médecine Interne, Centre Hospitalier Universitaire de Toulouse, France \\ 7: Service de Médecine Interne et Maladies Infectieuses, Centre Hospitalier Universitaire de Poitiers, France \\ 8: Service de Médecine Interne, Centre Hospitalier de Metz-Thionville, France \\ 9: Service de Médecine Interne, Centre Hospitalier de Charleville-Mézières, France \\ 10: Service de Médecine Interne, Centre Hospitalier Universitaire de Besançon, France \\ 11: Service de Dermatologie, Centre Hospitalier Universitaire de Besançon, University of Franche-Comté; INSERM UMR1098; SFR FED \\ 4234 IBCT, Besançon, France \\ 12 : Service de Dermatologie, Hôpital Henri Mondor, AP HP, Université Paris Est, France. \\ 13 : Service de Dermatologie, Centre Hospitalier Universitaire de Reims, France \\ 14 : Service de Dermatologie, Hôpital Tenon, AP HP, Université Pierre et Marie Curie, France \\ 15: Service de Médecine Interne, Centre Hospitalier Universitaire de St Etienne, France \\ 16: Service de Médecine Interne et Maladies Infectieuses, Centre Hospitalier Universitaire de Bordeaux, France \\ 17: Service de Maladies Infectieuses, Centre Hospitalier Universitaire de Grenoble, France \\ 18: Service de Médecine Interne 2, Hôpital La Pitié-Salpétrière, AP HP, Université Pierre et Marie Curie, France \\ 19: Service de Médecine Interne, Centre Hospitalier Universitaire de Caen, France \\ 20: Service de Médecine Interne, Hôpital Tenon, AP HP, Université Pierre et Marie Curie, France \\ 21: Service de Dermatologie, Hôpital Saint Louis, AP HP, Université Diderot, France \\ 22: Service de Médecine Interne, Centre Hospitalier Universitaire d'Amiens, France \\ 23: Service de Médecine Interne, Centre Hospitalier de Creil, France \\ 24: Service de Médecine Interne, Hôpital Nord, AP HM, France \\ 25: Service de Pneumologie, Centre Hospitalier Universitaire de Rennes, France \\ 26: Service de Médecine Interne, DHUi2B, Hôpital Saint Antoine, AP HP, Université Pierre et Marie Curie, France \\ 27: Service de Médecine Interne, Hôpital Cochin, Centre de Référence Maladies Systémiques et Autoimmunes Rares, AP HP, Université \\ Paris Descartes, France \\ 28: Service de Médecine Interne, Hôpital Jean Verdier, AP HP, Université Leonard de Vinci, France \\ 29: Service de Rhumatologie Pédiatrique, Centre de Référence des Maladies Auto-Inflammatoires de l'enfant, Hôpital Bicêtre, AP HP, \\ Université Paris Sud, France.
}

Correspondence: Dr Jean-Baptiste Fraison, Service de Médecine Interne, Hôpital St Louis, AP HP, 75010 Paris, Université Paris Diderot, France, Fax number: (+33) 1424997 80, phone number: (+33) 1424997 69, e-mail: jeanbaptiste.fraison@aphp.fr

Word count: 3020 words, abstract word count: 246 words; Figure and table: 6 . 


\section{Abstract \\ Objective}

Kawasaki disease (KD) is a vasculitis that mostly occurs in young children and rarely in adults. We analyzed the characteristics of adult-onset KD (AKD) in France.

\section{Methods}

We collected retrospective and prospective data for patients with a diagnosis of $\mathrm{KD}$ occurring after the age of 18 years. Cases were obtained via various French medical networks and identified from the international literature.

\section{Results}

We included 43 patients of AKD at 26 institution from 1992 to 2015, with mean (SD) age 30 (11) years (range 18-68) and sex ratio (M/F) 1.2; 34 patients met the American Heart Association criteria and 9 were incomplete AKD. The median time to diagnosis was 13 days (interquartile range 8-21). The main symptoms were fever (100\%), exanthema (98\%), changes in the extremities (91\%), conjunctivitis $(77 \%)$, oral cavity changes $(89 \%)$, cervical adenitis (55\%) and cardiac abnormalities (45\%). Overall, $35 \%$ of patients showed large-vessel vasculitis: coronary vasculitis $(26 \%)$ and coronary aneurysm (19\%). Treatment was mostly intravenous immunoglobulins (79\%) and aspirin (81\%). Four patients showed myocardial infarction due to coronary vasculitis, but none were treated with IVIg because of late diagnosis. After a median follow-up of 5 months (range 1-117), persistent aneurysm was noted in $9 \%$ of cases. Damage was significantly lower with early treatment than late or no treatment $(\mathrm{p}=0.01)$.

\section{Conclusion}

Given the high frequency of cardiac involvement and complications in this series of AKD, diagnosis and treatment should not be delayed, and early IVIg treatment seems to improve the outcome. 


\section{Key words:}

Mucocutaneous Lymph Node Syndrome, adult, intravenous immunoglobulin.

\section{Introduction}

Kawasaki disease (KD), also known as mucocutaneous lymph node syndrome, is an acute necrotizing vasculitis of the medium and small-sized arteries with severity related to coronary aneurysm[1]. First described in Japan in 1967[2], KD occurs in both endemic and communitywide epidemic forms in children of all races[3,4]. A genetic susceptibility has been identified by genome-wide association study (GWAS), but to date, the pathophysiology remains unclear[5].

Adult-onset KD (AKD) is rare and often misdiagnosed. A recent review including post-infectious cases described 100 cases of $A K D[6]$. Most reports were of 1 or 2 cases, and data were often missing, especially for infectious disease investigations as a differential diagnosis, detection of coronary abnormalities and long-term outcome. Although AKD is rare, it can be devastating, and many questions remain regarding its optimal management, especially treatment with intravenous immunoglobulin (IVIg) with late diagnosis.

To improve our knowledge and management of $\mathrm{AKD}$, we report a series of $\mathrm{AKD}$ from France.

\section{Methods:}

First, we searched for case reports of AKD in France that were published in English and/or French from 1967 (when KD was first described) through July 2015 in MEDLINE via PubMed and the National Library of Medicine. Then we contacted the authors of the reports for approval to include the cases in this report. Furthermore, we searched for other cases in the French Vasculitis Study Group (FVSG) database and in posters presented at the French Society of Internal Medicine (SNFMI) meetings. The aim of this study was presented at the annual meeting of Internal Medicine, Dermatology and Rheumatology in December 2014. We 
placed a call for cases on the website of the French Club Rhumatismes et Inflammation (www.cri-net.com/recherche/index.asp) and on the French KD registry "Kawanet".

We included cases that fulfilled the international diagnosis criteria for $\mathrm{KD}[7]$. A complete diagnosis is defined by the presence of unexplained fever $>5$ days and 4 of the 5 main clinical features: 1) extremity changes starting with edema or erythema progressing to desquamation of feet and hands 2) polymorphous exanthema, 3) bilateral conjunctivitis without exudates, 4) oral changes including injected pharynx or lips, and 5) cervical lymphadenopathy $>1.5 \mathrm{~cm}$. Incomplete $\mathrm{KD}$ is defined by 3 of the above 5 criteria and coronary artery disease. To be included in this AKD series, patient had to have onset of manifestations after the age of 18 years.

We excluded cases with 1) drug hypersensitivity, staphylococcal scalded skin syndrome, infectious disease, inflammatory and autoimmune disease that could explain all or some of the clinical manifestations[8]; 2) unknown HIV serology status; 3) onset of some clinical findings before age 18; and 4) incomplete cases without coronary artery disease.

Participating physicians systematically collected data on 1) gender, date of birth, date of diagnosis, co-morbidities and cardiovascular risk factors; 2) disease phenotype, including clinical, laboratory and cardiovascular findings; 3) treatment, including dates of initiation and discontinuation, concomitant treatment and adverse effects; and 4) outcome including clinical and cardiovascular features. Vasculitis Damage Index (VDI)[9] and Birmingham Vasculitis Activity Score (BVAS)[10] at diagnosis and at latest news were retrospectively determined and analyzed.

Coronary vasculitis was defined by at least one of the following features: CT and CT angiography findings of concentric mural thickening of the artery wall and in the venous phase, presence of a "double ring" enhancement pattern[11]; ultrasonography or echocardiography findings of a hyperechogenic artery wall[7,11]; and MRI findings of 
thickened artery wall in T1 or T2 echo-spin images and presence of wall edema in short tau inversion recovery images[11]. Aneurysm was defined by an increase in artery caliber as compared with adjacent segments and loss of parallelism of the artery wall[11]. Early treatment was defined by IVIG infusion before day 9 after AKD onset and late treatment was defined by IVIG infusion after day 10 of onset. We compared early treatment and late or no treatment.

\section{Statistical analysis}

The Fisher exact test was used for comparing qualitative data and the Wilcoxon test for quantitative data by use of R 3.2.1 (2015) with the Package Rcmdr 2.1.7 (2007). $\mathrm{P}<0.05$ was considered statistically significant.

This study was approved by Institutional research board Ile de France VII and National Council of Information and Freedoms.

\section{Results}

We collected 56 patients of AKD; 13 were excluded because of unknown HIV serology $(n=5)[12-16]$; presence of ankylosing spondylitis associated with an atypical evolution $(\mathrm{n}=1)[17]$; recurrent palmo plantar psoriasis $(\mathrm{n}=1)$; KD case associated with Chikungunya infection $(n=1)$ or Streptococcus infection $(n=1)$; incomplete cases without coronary artery disease $(n=2)$ and unknown age of onset $(n=1)$ or age $<18$ years $(n=1)$. Within the remaining 43 AKD patients, $28(65 \%)$ were reported in the literature[18-33]. AKD diagnosis was complete for $79 \%$ of patients $(n=34)$ and incomplete for $21 \%(n=9)$ (Table 1$)$. The cases were diagnosed between 1992 and 2015 in 26 different French centers (Figure 1). Internal medicine departments were the most represented (58\% of cases); $21 \%$ of cases were diagnosed by cardiologists, $12 \%$ by dermatologists, $7 \%$ by infectious diseases specialists and $2 \%$ in intensive care unit. 
The mean (SD) age at diagnosis was 31 (11) years (range 18-68). The male to female ratio was 1.2. All patients were living in France but had various ethnic backgrounds: 26/43 were Caucasian (60\%), 7 were from Africa (16\%), 2 were from the Caribbean (5\%), 1 was from Asia (2\%) and 1 was from the Middle East (2\%); data were not available for $6(14 \%)$.

None of the patients had a pediatric medical history of KD. Thirteen $(30 \%)$ had at least one cardiovascular risk factor at the time of AKD diagnosis: active smoking (26\%; median pack-years 11 [range 1-25]), history of smoking (7\%), hypercholesterolemia (9\%), hypertension (7\%) and type II diabetes mellitus (7\%). Two patients had had cardiovascular disease: one smoker patient with high blood pressure had had myocardial infarction (MI, patient 23) and one had had idiopathic pericarditis 10 years before AKD diagnosis (patient 22). Other notable medical histories included IgA vasculitis (patient 8), asthma (patient 15) and erythema multiform (patient 29).

\section{Clinical characteristics (Table 2)}

The median time from AKD to diagnosis was 13 days (IQR 8-21; range 0-3280). Fourtyseven $\%$ of the cases $(n=20)$ showed a seasonal peak in disease onset between October and February (Figure 2). AKD clinical manifestations included fever (100\%) that lasted a median of 13 days (IQR 10-18; range 4-64), changes in the extremities (91\%) with peeling (77\%) after a median delay of 13 days (IQR 11-17; range 2-45), hands and feet edema (61\%) and extremity rash (74\%). Apart from extremity rash, diffuse exanthema was present in $98 \%$ of cases and described in 81\%: measles-like (47\%), scarlatiniform (16\%), polymorphous $(9 \%)$, transient (7\%) and rubella-like (2\%). Patients also showed oral mucosa and lip changes (91\%) with oropharyngeal injection (61\%), dry fissured lips $(72 \%)$, strawberry tongue $(47 \%)$; bilateral non-exudative conjunctivitis (81\%) and cervical lymphadenopathy (56\%). Cardiac 
manifestations were reported in $44 \%$ of cases: chest pain $(23 \%)$, cardiogenic shock $(5 \%)$, left (9\%) and right heart failure (5\%). The mean (SD) initial BVAS was 8 (4) (range 3-18).

On admission, median C-reactive protein level was 205 mg/L (IQR 104-298; range 54-540) and first-hour erythrocyte sedimentation rate was $70 \mathrm{~mm}$ (IQR 48-90; range 4-112). Other biological abnormalities are in Table 3.

\section{$\underline{\text { Cardiovascular findings at diagnosis }}$}

Cardiac involvement was screened in all patients by echocardiography (93\%), coronary CT angiography $(33 \%)$, coronary angiography $(19 \%)$, stress test $(16 \%)$ and cardiac MRI (7\%). In total, 19 patients (44\%) had echocardiography only without further investigations; 3 patients (7\%) also underwent extracoronary angiography.

Initial echocardiography was abnormal for 19 patients cases (44\%) and revealed pericarditis (26\%), myocarditis (14\%) associated with pericarditis (7\%), hyperechogenic coronary arteries $(14 \%)$, coronary aneurysm (5\%), systolic dysfunction (16\%), hypokinesia (16\%), akinesia (7\%), valvulopathy $(2.5 \%)$ and intracavity thrombosis $(2.5 \%)$.

Overall, 35\% of patients showed evidence of large-vessel vasculitis (LVV), including coronary and extra-coronary arteries; $11(26 \%)$ presented evidence of coronary vasculitis and $8(19 \%)$ evidence of coronary aneurysm by coronary angiography (63\%), coronary CT angiography (25\%) or echocardiography (13\%). Eleven patients showed coronary vasculitis on 20 locations: left anterior descending $(n=7)$, left main coronary $(n=4)$, right coronary $(n=3)$, circumflex $(n=3)$ and diagonal branch $(n=3)$. Eight patients showed coronary aneurysms on 15 locations: right coronary $(n=5)$, left anterior descending $(n=4)$, left main coronary $(n=4)$, circumflex $(n=1)$ and diagonal branch $(n=1)$.

In all, 4 cases $(9 \%)$ featured MI, none treated with intravenous immunoglobulin (IVIg), because of diagnosis delay after the MI onset; all had documented evidence of coronary 
aneurysm (patients 1, 7, 10 and 20). Atherosclerosis (2\%) was found in one 52-year-old active smoker (20 pack-years) receiving treatment for type II diabetes mellitus and hypercholesterolemia. This patient also presented evidence of coronary vasculitis on coronary CT angiography.

Two cases (5\%) featured peripheral vasculitis: a 22 -year-old male who presented right brachial aneurysm and coronary aneurysm, spleen artery vasculitis and bilateral occlusion of lower-limb distal arteries complicated by acute lower-limb ischemia[26]; and a 29-year-old female who presented gastroduodenal and splenic artery vasculitis complicated by spleen infarcts without coronary aneurysm[20].

Presence of at least one cardiovascular risk factor was not significantly associated with LVV ( $50 \%$ of cases with LVV vs $25 \%$ without, $\mathrm{p}=0.16)$. The proportion of cases with echocardiography as the sole investigation without further cardiac check-up did not differ by presence or absence of LVV (33\% with LVV vs 50\% without, $\mathrm{p}=0.35)$.

\section{Treatment and disease course (Table 4)}

In total, 34cases (79\%) received IVIg at a median of 11 days (IQR 9-18; range 1-69) after the beginning of the disease; $12(28 \%)$ had early treatment. Most (91\%) received a single course of IVIg, $6 \%$ received 2 courses and 3\% received 4 . The infusion dose was $2 \mathrm{~g} / \mathrm{kg}$ for $94 \%$ of patients, and $1.6 \mathrm{~g} / \mathrm{kg}$ for $6 \%$. Duration of IVIg was 1 day (17\%), 2 days (45\%), 3 days (7\%), 4 days (3\%) and 5 days (28\%). Fever disappeared after a median of 2 days (range $0-4)$ for $91 \%$ of patients. Apyrexia delay after IVIg seems longer with early treatment versus late treatment: 2 days (IQR 2-3, range 1-4) versus 1.5 (IQR 1-2, range $0-4)(\mathrm{p}=0.07)$ (Table 4).

Patients with early IVIg treatment versus late or no treatment did not differ in frequency of LVV (33\% vs 35\%, p=1) but did differ in fever duration: median 10 days (IQR 8-11; range 4-12) versus 16 (IQR 11-21; range 5-64) $(\mathrm{p}=0.002)$ (Table 4). The initial BVAS 
was significantly lower in the early than late or no treatment group: median 4 (IQR 3-6.5; range 3-13) versus 9 (IQR 5-11; range 3-18) in late or no treatment group $(\mathrm{p}=0.006)$ (Table 4).

Most patients (86\%) received aspirin: $24(56 \%)$ had an anti-inflammatory dose and 24 $(56 \%)$ an anti-aggregant dose; $23(53 \%)$ received IVIg plus aspirin at an anti-inflammatory dose. In the early-treated group, $83 \%$ of patients received aspirin at an anti-inflammatory dose versus $45 \%$ in the late or untreated group $(\mathrm{p}=0.04)$. The other anti-inflammatory drugs used were steroids (14\%), non-steroidal anti-inflammatory drugs $(7 \%)$ and colchicine $(5 \%)$. The use of cardiovascular drugs was reported for $28 \%$ of patients and included curative anticoagulation (12\%) (without reported hemorrhage), angiotensin-converting enzyme inhibitors $(16 \%)$, beta-blockers (12\%), spironolactone $(5 \%)$ and amiodarone $(2 \%)$.

The median duration of follow-up after diagnosis was 5 months (IQR 2-19; range 1117) and seems higher for patients with than without LVV: median 11 months (IQR 4-22; range 1-117) versus 4 (IQR 2-13; range 1-78) $(\mathrm{p}=0.14)$. After 6 months, the proportion of coronary aneurysm detected by cardiac imaging decreased from $19 \%$ to $14 \%$ and to $9 \%$ at the end of the follow-up. The median BVAS decreased to 0 (range 0-6) at the end of follow-up.

Late complications included bilateral lower-limb ischemia with gangrene requiring a trans-metacarpal-level amputation in 1 patient $(2 \%)$ and heart failure at the end of follow-up in 2 patients $(5 \%)$. The median VDI was 0 (IQR $0-1$, range $0-6)$. The VDI was significantly lower with early than late or no treatment: median 0 (range $0-1$ ) versus 0 (range 0-6) for cases with late or no treatment $(\mathrm{p}=0.01)$ (Table 4). No death was reported but one untreated patient relapsed after 1 month (patient 25).

\section{Discussion}

We report here the largest series of patients with adult-onset KD. These patients had a high frequency of cardiac involvement and complications, and MI and damage may be less 
frequent with early IVIg treatment than late or no treatment. These results seem similar to those found for childhood KD (CKD)[7].

The BVAS and VDI are commonly used in adult vasculitis monitoring. In children, these scores are modified as the Pediatric Vasculitis Activity Score (PVAS)[34] and Pediatric VDI (PVDI)[35], respectively, but are not yet used in KD.

Our literature search of AKD found 25 infections mimicking KD: post-HIV infection $(n=20)[36-49]$, Epstein-Barr virus infection $(n=1)[50]$, Streptococcus infection $(n=2)[51]$, Coxiella infection $(n=1)[52]$ and Chikungunya infection $(n=1)$. In our literature analysis, we did not include complications of known or suspected KD in childhood, infectious cases $(n=25)$ and inaccessible cases $(n=10)[53-62]$.

The total reported cases of $\mathrm{AKD}$ in the PubMed database represents 41 non-French complete cases[6,8,63-101] and 5 incomplete cases[102-106]. Some reports published between 1976 and 1996 were inaccessible $(n=10)$ [53-62]. Including non-French cases $(n=46)$, our observations ( $\mathrm{n}=43$ ), 89 observations of non-HIV AKD have been reported since 1979.

The American Heart Association diagnostic criteria seem applicable for AKD, with the complete form being the most frequent. Most of the incomplete cases were diagnosed by the presence of coronary vasculitis. A few cases were retrospectively diagnosed after MI complicating coronary aneurysm[26,33], as observed in this series.

$\mathrm{AKD}$ clinical signs appeared comparable to those for $\mathrm{CKD}$, but the frequency of clinical signs could differ between the 2 groups. In the pediatric study of Saundankar et al., in 2014[107], the frequency of signs we found were similar to that cited for adult polymorphous exanthema (98\% vs 96\%). Coronary aneurysm in our adult patients with late or no treatment seemed as prevalent as in children $(19 \%$ vs $15-25 \%[7,108])$. Some symptoms less common for adults than children included oropharynx changes ( $91 \%$ vs $96 \%$ ). 1ymphadenopathy (56\% vs $63 \%$ ), conjunctivitis ( $81 \%$ vs $89 \%$ ) and gastrointestinal symptoms ( $56 \%$ vs $60 \%)$, whereas 
symptoms more common for adults than children were changes in extremities ( $91 \%$ vs $76 \%$ ) and arthritis (42\% vs $28 \%)$. AKD disease appears to share other features with CKD such as pericarditis, myocarditis, cardiac shock and neurological manifestations such as aseptic meningitis ${ }^{5}$. In addition, adult biological findings were similar to those found in children, with a marked increase in acute-phase reactants, delayed thrombocytosis, hyponatremia, hepatic cytolysis and aseptic leukocyturia[7]. We found 16\% hypereosinophilia in our adult cases with $36 \%$ reported in $\operatorname{CKD}[109,110]$. In the extra-tropical latitudes of the northern hemisphere, a winter peak in CKD has been long observed[111]. To our knowledge, this is the first time the same seasonal pattern has been highlighted in AKD.

Given the exceptional nature and the need to rule out many differential diagnoses, the diagnosis of $\mathrm{AKD}$ is late and probably underdiagnosed. The differential diagnosis of AKD include: drug hypersensitivity reactions, toxic shock syndrome, erythema multiforme, scarlet fever, measles, rubella, parvovirus, infectious mononucleosis, hand-foot-and-mouth syndrome, leptospirosis, rocky mountain and Mediterranean spotted fever, syphilis, endocarditis, rheumatic fever, Reiter syndrome, palmoplantar psoriasis, Behçet disease, polyarteritis nodosa, Bazex syndrome, etc[8,33]. Hence, the diagnostic delay is longer for AKD than CKD, for which it is usually $<7$ days[7]. In addition, physicians must consider cardiovascular risk factors during the acute phase of AKD to avoid further cardiovascular complications due to the development of atherosclerosis[112].

In general, $\mathrm{AKD}$ is less treated than CKD[113]. IVIg was given for only $79 \%$ of our adult cases and was combined with aspirin at an anti-inflammatory dose for $53 \%$. Undertreatment of AKD can be explained by the natural history of the disease, which can vanish spontaneously without treatment, and by the absence of treatment standardization in cases diagnosed after 10 days of fever. However, even when administered late, IVIg seemed effective to control fever in $91 \%$ of patients, but vasculitis is not $100 \%$ preventable. For $21 \%$ 
of cases, late diagnosis and the absence of a gold standard treatment was associated with a higher coronary aneurysm rate as compared with well-treated CKD[7]. Of note, the initial cardiac event rate was high, with $44 \%$ cardiac impairment and $44 \%$ abnormal echocardiography findings. The presence of extracoronary vasculitis in CKD is rarely described[114], as compared with $5 \%$ of our AKD cases.

Given the severity of coronary aneurysm, all patients, especially those with cardiac manifestations, should be screened for coronary vasculitis. Most of our cases of incident coronary aneurysm $(86 \%)$ were diagnosed by coronary angiography or coronary CT angiography. Considering the limitations of echocardiography to entirely view coronary arteries in adults, this screening should include, in addition to echocardiography, coronary angiography, coronary CT angiography and/or cardiac MRI[115]. However, coronary angiography is not the best morphological exam for coronary injury screening. Coronary angiography detects later and more severe injuries such as stenosis, aneurysm and thrombosis. It does not seem able to detect early wall-artery injuries that are more easily seen by coronary CT angiography[116] or echocardiography[117].

Although the pathophysiology of KD is becoming better understood, specifically the genetics mechanism[118], it still remains unclear. Recently, GWAS revealed an association of many genes: the ITPKC gene implicated in negative regulation of $\mathrm{T}$ cells via an NFAT pathway[119] and the FcRg2a gene associated with susceptibility to KD and also linked to IVIg response[120]. Genetic polymorphism might explain why the risk of KD could be delayed in adults. There is also a better understanding of the inflammation process: HMGB1 could get involved in KD by amplifying the inflammation[121].

Although original, our study remains limited by its retrospective design, which prevented an exhaustive collection of data, and by a probable selection bias toward the most severe cases. Indeed, cardiovascular manifestations may be the symptom suggesting a 
diagnosis of KD among adult physicians, and lead to a possible overestimation of this complication in this age group.

\section{Conclusion}

KD remains an exceptional disease in adulthood, but all cases may not have been diagnosed and are probably underreported. The high rate of cardiac complications might be related to both a long diagnosis delay and absence of IVIg treatment. An increased awareness of adult $\mathrm{KD}$ is warranted in the medical community, because AKD carries a serious prognosis in the short and long term, with irreversible damage in the absence of prompt management.

\section{Funding sources}

There are no relevant funding sources to declare.

\section{Disclosure}

There is no relevant financial relationship to declare for all authors. 


\section{References:}

[1] Jennette JC, Falk RJ, Bacon PA, Basu N, Cid MC, Ferrario F, et al. 2012 revised International Chapel Hill Consensus Conference Nomenclature of Vasculitides. Arthritis Rheum 2013;65:1-11. doi:10.1002/art.37715.

[2] Kawasaki T. [Acute febrile mucocutaneous syndrome with lymphoid involvement with specific desquamation of the fingers and toes in children]. Arerugi Allergy 1967;16:178-222.

[3] Ramos-Casals M, Brito-Zerón P, Kostov B, Sisó-Almirall A, Bosch X, Buss D, et al. Google-driven search for big data in autoimmune geoepidemiology: analysis of 394,827 patients with systemic autoimmune diseases. Autoimmun Rev 2015;14:670-9. doi:10.1016/j.autrev.2015.03.008.

[4] Greco A, De Virgilio A, Rizzo MI, Tombolini M, Gallo A, Fusconi M, et al. Kawasaki disease: an evolving paradigm. Autoimmun Rev 2015;14:703-9. doi:10.1016/j.autrev.2015.04.002.

[5] Yim D, Curtis N, Cheung M, Burgner D. Update on Kawasaki disease: epidemiology, aetiology and pathogenesis. J Paediatr Child Health 2013;49:704-8. doi:10.1111/jpc.12172.

[6] Kontopoulou T, Kontopoulos DG, Vaidakis E, Mousoulis GP. Adult Kawasaki disease in a European patient: a case report and review of the literature. J Med Case Reports 2015;9:75. doi:10.1186/s13256-015-0516-9.

[7] Newburger JW, Takahashi M, Gerber MA, Gewitz MH, Tani LY, Burns JC, et al. Diagnosis, treatment, and long-term management of Kawasaki disease: a statement for health professionals from the Committee on Rheumatic Fever, Endocarditis, and Kawasaki Disease, Council on Cardiovascular Disease in the Young, American Heart Association. Pediatrics 2004;114:1708-33. doi:10.1542/peds.2004-2182.

[8] Drago F, Javor S, Ciccarese G, Cozzani E, Parodi A. A Case of Complete Adult-Onset Kawasaki Disease: A Review of Pathogenesis and Classification. Dermatology 2015. doi:10.1159/000381911.

[9] Exley AR, Bacon PA, Luqmani RA, Kitas GD, Gordon C, Savage CO, et al. Development and initial validation of the Vasculitis Damage Index for the standardized clinical assessment of damage in the systemic vasculitides. Arthritis Rheum 1997;40:371-80.

[10] Mukhtyar C, Lee R, Brown D, Carruthers D, Dasgupta B, Dubey S, et al. Modification and validation of the Birmingham Vasculitis Activity Score (version 3). Ann Rheum Dis 2009;68:1827-32. doi:10.1136/ard.2008.101279.

[11] Ammirati E, Moroni F, Pedrotti P, Scotti I, Magnoni M, Bozzolo EP, et al. Noninvasive imaging of vascular inflammation. Front Immunol 2014;5:399. doi:10.3389/fimmu.2014.00399.

[12] Montagnac R, Czertok G, Lesavre P, Schillinger F. [Kawasaki syndrome in a young adult. Dermatologic and immunologic study]. Sem Hop 1982;58:2538-42.

[13] Chavanet P, Portier H, Escalier F, Courtois B. Intravenous gammaglobulin for adult Kawasaki disease. Lancet 1985;2:1184-5.

[14] Leclerc G, Bégin P, Laramée P, Genest P. Transient heart failure in an adult with Kawasaki disease. Clin Cardiol 1986;9:128-30.

[15] Lucht F, Fresard A, Bonnefille E, Lamaud C, Rousset H. [Aseptic purulent meningitis in Kawasaki syndrome in an adult]. Presse Med 1988;17:1763-4.

[16] Machet L, Vaillant L, Goutal H, Lanternier G, Khallouf R, Chagnon JL, et al. Kawasaki disease in a young adult with a perineal rash. Br J Dermatol 1990;123:413-4. 
[17] Soltner E, Neel A, Tiab M, Varin S, Cormier G, Maisonneuve H, et al. Chronic, eventually fatal, Kawasaki-like disease in an adult with spondylarthropathy responding to IVIG therapy. Jt Bone Spine 2009;76:559-61. doi:10.1016/j.jbspin.2009.01.006.

[18] Bayrou O, Phlippoteau C, Bonte I, Pecquet C, Leynadier F. [Kawasaki syndrome in adults with perineal eruption]. Ann Dermatol Venereol 1992;119:839-40.

[19] Couilliet D, Grange F, Guillaume JC. [A case for diagnosis: Kawasaki disease in the adult]. Ann Dermatol Venereol 1994;121:905-6.

[20] Huong DL, Gatfosse M, Papo T, Barjonet G, Lacombe P, Godeau P. Symptomatic splenic infarction complicating adult Kawasaki disease. Br J Rheumatol 1995;34:579_ 80.

[21] Pavese P, Brion JP, Meusnier T, Stahl JP. [Kawasaki syndrome in adults: treatment with polyvalent intravenous immunoglobulins]. Ann Med Interne 1997;148:287-8.

[22] Reynaud-Mendel B, Lemann M, David F, Menasché S, Bachelez H, Dubertret L. Adult Kawasaki disease complicated by pancreatitis. Am J Gastroenterol 1997;92:1239-40.

[23] Bachmeyer C, Turc Y, Curan D, Duval-Arnould M. Anterior uveitis as the initial sign of adult Kawasaki syndrome (mucocutaneous lymph node syndrome). Am J Ophthalmol 2000;129:101-2.

[24] Brinchault G, Noyon V, Roussel M, Gacouin A, Michelet C. [Kawasaki's disease in adults: a case report]. Presse Med 1983 2003;32:165.

[25] Granel B, Serratrice J, Ene N, Igual J-P, Habib G, Disdier P, et al. Painful jaundice revealing Kawasaki disease in a young man. J Gastroenterol Hepatol 2004;19:713-5. doi:10.1111/j.1440-1746.2002.02903.x.

[26] Bonté I, Mahr A, Laroche L, Guillevin L, Robineau M. Peripheral gangrene in adultonset Kawasaki disease. Scand J Rheumatol 2005;34:71-3.

[27] Sève P, Stankovic K, Smail A, Durand DV, Marchand G, Broussolle C. Adult Kawasaki disease: report of two cases and literature review. Semin Arthritis Rheum 2005;34:785-92. doi:10.1016/j.semarthrit.2005.01.012.

[28] Galempoix J-M, Kaeppler E, Lanoux P, Belaïda A, Aboutara M, Penalba C. [Kawasaki adult disease: case report]. Rev Med Interne 2006;27:646-9. doi:10.1016/j.revmed.2006.04.007.

[29] Sbidian E, Lacert A, Perrin P, Le Cleach L. Syndrome de Kawasaki de l'adulte. Ann Dermatol Venereol 2009;136:260-3. doi:10.1016/j.annder.2008.06.012.

[30] Bresson V, Bonello B, Rousset-Rouvière C, Serratrice J, Chabrol B, Dubus J-C, et al. [Kawasaki disease in older children and young adults: 10 years of experience in Marseille, France]. Arch Pediatrie 2011;18:731-6. doi:10.1016/j.arcped.2011.04.014.

[31] Guillet S, Freund Y, Morel N, Francès C, Amoura Z, Piette J-C, et al. [Strawberry tongue and red eyes]. Rev Med Interne 2012;33:405-6.

doi:10.1016/j.revmed.2011.08.011.

[32] Dauphin C, Motreff P, Souteyrand G, Laurichesse H, Gourdon F, Lesens O, et al. [Kawasaki disease is also a disease of adults: report of six cases]. Arch Mal Coeur Vaiss 2007;100:439-47.

[33] Gomard-Mennesson E, Landron C, Dauphin C, Epaulard O, Petit C, Green L, et al. Kawasaki disease in adults: report of 10 cases. Medicine (Baltimore) 2010;89:149-58. doi:10.1097/MD.0b013e3181df193c.

[34] Demirkaya E, Ozen S, Pistorio A, Galasso R, Ravelli A, Hasija R, et al. Performance of Birmingham Vasculitis Activity Score and disease extent index in childhood vasculitides. Clin Exp Rheumatol 2012;30:S162-8.

[35] Eleftheriou D, Varnier G, Dolezalova P, McMahon A-M, Al-Obaidi M, Brogan PA. Takayasu arteritis in childhood: retrospective experience from a tertiary referral centre 
in the United Kingdom. Arthritis Res Ther 2015;17:36. doi:10.1186/s13075-015-05451.

[36] Rauch AM, Fultz PN, Kalyanaraman VS. Retrovirus serology and Kawasaki syndrome. Lancet 1987;1:1431.

[37] Viraben R, Dupre A. Kawasaki disease associated with HIV infection. Lancet 1987;1:1430-1.

[38] Bayrou O, Phlippoteau C, Artigou C, Haddad T, Leynadier F. Adult Kawasaki syndrome associated with HIV infection and anticardiolipin antibodies. J Am Acad Dermatol 1993;29:663-4.

[39] Wolf CV, Wolf JR, Parker JS. Kawasaki's syndrome in a man with the human immunodeficiency virus. Am J Ophthalmol 1995;120:117-8.

[40] Yoganathan K, Goodman F, Pozniak A. Kawasaki-like syndrome in an HIV positive adult. J Infect 1995;30:165-6.

[41] Porneuf M, Sotto A, Barbuat C, Ribou G, Jourdan J. Kawasaki syndrome in an adult AIDS patient. Int J Dermatol 1996;35:292-4.

[42] Martínez-Escribano JA, Redondo C, Galera C, Sánchez-Pedreño P, Abel JL, Frías JF. Recurrent Kawasaki syndrome in an adult with HIV-1 infection. Dermatol 1998;197:96-7.

[43] Muniain-Ezcurra M, Bueno-Mariscal C, Rodríguez-Baño J, Domínguez-Castellano A, Balonga-Tomás B, Ríos-Villegas MJ, et al. Kawasaki disease and parvovirus B19 infection in an adult HIV-1-infected patient. Clin Microbiol Infect 1998;4:609-10.

[44] Johnson RM, Little JR, Storch GA. Kawasaki-like syndromes associated with human immunodeficiency virus infection. Clin Infect Dis 2001;32:1628-34. doi:10.1086/320523.

[45] Barbaro G, Di Lorenzo G, Barbarini G. Kawasaki-like syndrome in an HIV-infected adult. Rheumatol Oxf Engl 2003;42:1427-9. doi:10.1093/rheumatology/keg365.

[46] Blanchard JN, Powell HC, Freeman WR, Letendre S, Blanchard D, Shimizu C, et al. Recurrent Kawasaki disease-like syndrome in a patient with acquired immunodeficiency syndrome. Clin Infect Dis 2003;36:105-11. doi:10.1086/345465.

[47] Ball SC. Kawasaki-like disease in an HIV-infected patient. AIDS Read 2005;15:414-6.

[48] Velez AP, Menezes L, Crespo A. Kawasaki-like syndrome possibly associated with immune reconstitution inflammatory syndrome in an HIV-positive patient. AIDS Read 2006;16:464-6.

[49] Stankovic K, Miailhes P, Bessis D, Ferry T, Broussolle C, Sève P. Kawasaki-like syndromes in HIV-infected adults. J Infect 2007;55:488-94. doi:10.1016/j.jinf.2007.09.005.

[50] Barbour AG, Krueger GG, Feorino PM, Smith CB. Kawasaki-like disease in a young adult. Association with primary Epstein-Barr virus infection. JAMA 1979;241:397-8.

[51] Anderson DG, Warner G, Barlow E. Kawasaki disease associated with streptococcal infection within a family. J Paediatr Child Health 1995;31:355-7.

[52] Weir WR, Bouchet VA, Mitford E, Taylor RF, Smith H. Kawasaki disease in European adult associated with serological response to Coxiella burneti. Lancet 1985;2:504.

[53] Siegel CJ, Wenner HA. The mucocutaneous lymph node syndrome. Description of an affected 21-month-old child in Kansas City. Clin Pediatr (Phila) 1976;15:1105-6.

[54] Ishihara T, Owaki T, Kato H, Yanagihara K, Okumachi F, Takagi Y, et al. [Mucocutaneous lymphnode syndrome associated with coronary artery aneurysms and papillary muscle dysfunction: report of a case (author's transl)]. Kokyu To Junkan 1979;27:69-74.

[55] Watanabe J, Matsui Y, Hino K. [Two adult cases of mucocutaneous lymphnode syndrome (MCLS) (author's transl)]. Nihon Naika Gakkai Zasshi 1980;69:1637-43. 
[56] Pannarale G, Rizzi R, Loizzi P, Cantatone FP, Carrozzo M, Coratelli P.

[Glomerulonephritis in Kawasaki disease. A new pathology caused by immune complexes?]. Minerva Nefrol 1982;29:113-4.

[57] Marcella JJ, Ursell PC, Goldberger M, Lovejoy W, Fenoglio JJ, Weiss MB. Kawasaki syndrome in an adult: endomyocardial histology and ventricular function during acute and recovery phases of illness. J Am Coll Cardiol 1983;2:374-8.

[58] Berzi P, Innocenti R, Marra N. [Kawasaki's disease in a 22-year-old adult]. Recenti Prog Med 1988;79:176-8.

[59] Hettich R, Kühl U, Kemkes BM, Steinbeck G, Rienmüller R. [Increasing stress dyspnea in a 31-year-old patient with enlarged heart shadow]. Internist 1989;30:64-7.

[60] Seicshnaydre MA, Frable MA. Kawasaki disease: early presentation to the otolaryngologist. Otolaryngol--Head Neck Surg 1993;108:344-7.

[61] [A 31-year-old female with fever, arthritis, and heart conduction disorder]. Rev Clínica Esp 1994;194:183-92.

[62] Forsberg S, Rainio A. [Kawasaki disease in adult]. Duodecim 1996;112:2015-8.

[63] Everett ED. Mucocutaneous lymph node syndrome (Kawasaki disease) in adults. JAMA 1979;242:542-3.

[64] Lee TJ, Vaughan D. Mucocutaneous lymph node syndrome in a young adult. Arch Intern Med 1979;139:104-5.

[65] Glanzer JM, Galbraith WB, Jacobs JP. Kawasaki disease in a 28-year-old man. JAMA 1980;244:1604-6.

[66] Heenen M, Brimioulle S, Sternon J. [Kawasaki disease in an adult. Apropos of a case]. Rev Med Brux 1980;1:85-8.

[67] Milgrom H, Palmer EL, Slovin SF, Morens DM, Freedman SD, Vaughan JH. Kawasaki disease in healthy young adult. Ann Intern Med 1980;92:467-70.

[68] Saxe N, Horak A, Goldblatt J. Mucocutaneous lymph node syndrome in a young adult. A case report. South Afr Med J 1980;58:1011-3.

[69] Gomberg R, Hamm P, Martin A. Mucocutaneous lymph node syndrome (Kawasaki disease) in an adult. West J Med 1981;135:406-8.

[70] Takagi S, Oshimi K, Sumiya M, Gonda N, Kano S, Takaku F, et al. Adult onset mucocutaneous lymph node syndrome with coronary aneurysm. Am Heart J 1981;101:852-3.

[71] Hicks JT, Korenyi-Both A, Utsinger PD, Baran EM, McLaughlin GE. Neuromuscular and immunochemical abnormalities in an adult man with Kawasaki disease. Ann Intern Med 1982;96:607-10.

[72] Liebmann LI, Mikelic V, Joh MM, Wilson FM. Hydrops of the gallbladder in an adult with Kawasaki disease. JAMA 1982;247:827-9.

[73] Takamoto T, Niwa A, Taniguchi K, Takeuchi J. Acute febrile mucocutaneous lymph node syndrome (Kawasaki disease) in an adult. Clin Cardiol 1982;5:555-9.

[74] Burstein F, Metson R, Colman MF, Canalis RF. Kawasaki disease in adults. An otolaryngologist's perspective. Arch Otolaryngol 1984;110:543-5.

[75] Keim DE, Geltner JW. Mucocutaneous lymph node syndrome in an adult, with lymph node biopsy correlation. South Med J 1985;78:872-4.

[76] Servilla KS, Green JA, Williams HJ, Zone JJ. An unusual systemic staphylococcal illness with features of the mucocutaneous lymph node syndrome. West J Med 1985;142:257-9.

[77] Michels TC. Mucocutaneous lymph node syndrome in adults. Differentiation from toxic shock syndrome. Am J Med 1986;80:724-8.

[78] Barabe P, Mbaye E, Peghini M, Brullard B, Gueye PM. [First Senegalese case of Kawasaki's disease]. Presse Med 1987;16:1977-8. 
[79] Butler DF, Hough DR, Friedman SJ, Davis HE. Adult Kawasaki syndrome. Arch Dermatol 1987;123:1356-61.

[80] Patrick AL, Barton EN, Vincente JB. Kawasaki disease in an adult Trinidadian male. Trop Geogr Med 1988;40:254-6.

[81] Mcllroy MA, Fisher EJ, Saravolatz LD, Hardwicke MB, Wilson FM. Aseptic meningitis complicating adult Kawasaki disease: case report and review of the literature. Am J Med 1989;87:106-10.

[82] Thompson AC, Lamey PJ. Kawasaki syndrome in an adult. J Laryngol Otol 1990;104:37-8.

[83] Caputo AE, Roberts WN, Yee YS, Posner MP. Hepatic artery aneurysm in corticosteroid-treated, adult Kawasaki's disease. Ann Vasc Surg 1991;5:533-7. doi:10.1007/BF02015278.

[84] Tomiyama J, Hasegawa Y, Kumagai Y, Adachi Y, Karasawa K. Acute febrile mucocutaneous lymph node syndrome (Kawasaki disease) in adults: case report and review of the literature. Jpn J Med 1991;30:285-9.

[85] Paira SO, Roverano S. Kawasaki syndrome in a young adult. J Rheumatol 1992;19:488-90.

[86] Phillips WG, Marsden JR. Adult Kawasaki syndrome. Br J Dermatol 1993;129:330-3.

[87] Jackson JL, Kunkel MR, Libow L, Gates RH. Adult Kawasaki disease. Report of two cases treated with intravenous gamma globulin. Arch Intern Med 1994;154:1398-405.

[88] Vaiopoulos G, Sfifakis PP, Skoumas V, Christov E, Doukas E, Kaklamanis P. [Kawasaki's disease in a young adult]. Rev Rhum 1994;61:645-8.

[89] Herrero JB, Ornia N, Serrano O, Pinilla E, Fernandez Capitan C, Camacho J, et al. [Kawasaki's syndrome in the adult and bilateral sacroiliitis]. An Med Interna 1995;12:549-545.

[90] Hansen SK, Buhl MR. [Kawasaki syndrome in an adult]. Ugeskr Laeger 1998;160:1807-8.

[91] Shelleh HH, Khan SA, Khan LA, Al-Hateeti H, Iqbal S, Saleh AF. Adult Kawasaki disease. Saudi Med J 2000;21:1078-80.

[92] Hattori T, Matsukawa Y, Takei M, Yamaguchi K, Yamazaki T, Sawada U, et al. Adult Kawasaki disease unrelated to epstein-barr virus and group A Streptococcus. Intern Med Tokyo Jpn 2005;44:1182-4.

[93] Pérez-Rodon J, Aboal J, Morales M, Masià R. [Kawasaki disease with coronary artery lesions in adults]. Rev Esp Cardiol 2006;59:1203-4.

[94] El Karoui K, Servais A, Fadel F, Jablonski M, Fakhouri F, Lesavre P, et al. Acute renal failure and febrile rash--infectious or not? Adult Kawasaki disease (KD). Nephrol Dial Transplant 2007;22:949-51. doi:10.1093/ndt/gfl792.

[95] Wolff AE, Hansen KE, Zakowski L. Acute Kawasaki Disease: Not Just for Kids. J Gen Intern Med 2007;22:681-4. doi:10.1007/s11606-006-0100-5.

[96] Cunha BA, Pherez FM, Alexiadis V, Gagos M, Strollo S. Adult Kawasaki's disease with myocarditis, splenomegaly, and highly elevated serum ferritin levels. Heart Lung 2010;39:164-72. doi:10.1016/j.hrtlng.2009.06.007.

[97] de Cabo EE, García-Hortelano M, Ruiz-Rivas JL, García-Iglesias F, González-Alegre MT, Guinea J. [Adult Kawasaki disease]. Rev Clínica Esp 2010;210:e17-9. doi:10.1016/j.rce.2010.02.001.

[98] Seeberg KA, Selbekk BH. [A man presenting with fever and abdominal pain]. Tidsskr Den Nor Lægeforen 2010;130:1830-2. doi:10.4045/tidsskr.09.0385.

[99] Ugi J, Lepper PM, Witschi M, Maier V, Geiser T, Ott SR. Nonresolving pneumonia and rash in an adult: pulmonary involvements in Kawasaki's disease. Eur Respir J 2010;35:452-4. doi:10.1183/09031936.00132309. 
[100] Campos-Franco J, Lopez R, Alende R, Gonzalez-Quintela A. Adult Kawasaki Disease. Intern Med 2011;50:1443-4. doi:10.2169/internalmedicine.50.5344.

[101] Inokuchi R, Kurata H, Harada M, Aoki Y, Matsubara T, Doi K, et al. Coronary Artery Aneurysms After Adult-Onset Kawasaki Disease. Circulation 2013;127:1636-7. doi:10.1161/CIRCULATIONAHA.112.130153.

[102] Caron GA. Kawasaki disease in an adult. JAMA 1980;243:430.

[103] Montella F, Persico L, Recchia O. [The immune system in Kawasaki disease. Study of the 1 st case of the disease found in Italy in an adult subject]. Minerva Med 1985;76:711-6.

[104] Szabó L, Csányi A. [Adult-age Kawasaki disease]. Orv Hetil 1992;133:791-4.

[105] Fason JT, Fry YW, Smith D. Kawasaki disease in a postpartum patient. J Natl Med Assoc 2004;96:1499-502.

[106] Sarkar DA, Smith EEJ, Brecker SJ. Giant coronary aneurysms. Lancet 2004;363:37.

[107] Saundankar J, Yim D, Itotoh B, Payne R, Maslin K, Jape G, et al. The Epidemiology and Clinical Features of Kawasaki Disease in Australia. PEDIATRICS 2014;133:e1009-14. doi:10.1542/peds.2013-2936.

[108] Sánchez-Manubens J, Bou R, Anton J. Diagnosis and classification of Kawasaki disease. J Autoimmun 2014;48-49:113-7. doi:10.1016/j.jaut.2014.01.010.

[109] Tremoulet AH, Jain S, Chandrasekar D, Sun X, Sato Y, Burns JC. Evolution of laboratory values in patients with Kawasaki disease. Pediatr Infect Dis J 2011;30:10226. doi:10.1097/INF.0b013e31822d4f56.

[110] Terai M, Yasukawa K, Honda T, Jibiki T, Hirano K, Sato J, et al. Peripheral blood eosinophilia and eosinophil accumulation in coronary microvessels in acute Kawasaki disease. Pediatr Infect Dis J 2002;21:777-81. doi:10.1097/01.inf.0000024004.22235.ac.

[111] Burns JC, Herzog L, Fabri O, Tremoulet AH, Rodó X, Uehara R, et al. Seasonality of Kawasaki disease: a global perspective. PloS One 2013;8:e74529. doi:10.1371/journal.pone.0074529.

[112] Martin SS, Sperling LS, Blaha MJ, Wilson PWF, Gluckman TJ, Blumenthal RS, et al. Clinician-patient risk discussion for atherosclerotic cardiovascular disease prevention: importance to implementation of the 2013 ACC/AHA Guidelines. J Am Coll Cardiol 2015;65:1361-8. doi:10.1016/j.jacc.2015.01.043.

[113] Holve TJ, Patel A, Chau Q, Marks AR, Meadows A, Zaroff JG. Long-term Cardiovascular Outcomes in Survivors of Kawasaki Disease. PEDIATRICS 2014;133:e305-11. doi:10.1542/peds.2013-1638.

[114] Hoshino S, Tsuda E, Yamada O. Characteristics and Fate of Systemic Artery Aneurysm after Kawasaki Disease. J Pediatr 2015;167:108-12.e2. doi:10.1016/j.jpeds.2015.04.036.

[115] Goo HW, Park I-S, Ko JK, Kim YH. Coronary CT angiography and MR angiography of Kawasaki disease. Pediatr Radiol 2006;36:697-705. doi:10.1007/s00247-006-0182-6.

[116] Sohn S, Kim HS, Lee SW. Multidetector row computed tomography for follow-up of patients with coronary artery aneurysms due to Kawasaki disease. Pediatr Cardiol 2004;25:35-9. doi:10.1007/s00246-003-0559-3.

[117] Hiraishi S, Misawa H, Takeda N, Horiguchi Y, Fujino N, Ogawa N, et al. Transthoracic ultrasonic visualisation of coronary aneurysm, stenosis, and occlusion in Kawasaki disease. Heart 2000;83:400-5.

[118] Sawalha AH, Dozmorov MG. Epigenomic functional characterization of genetic susceptibility variants in systemic vasculitis. J Autoimmun 2015. doi:10.1016/j.jaut.2015.10.002. 
[119] Onouchi Y, Ozaki K, Burns JC, Shimizu C, Terai M, Hamada H, et al. A genome-wide association study identifies three new risk loci for Kawasaki disease. Nat Genet 2012;44:517-21. doi:10.1038/ng.2220.

[120] Kuo H-C, Chang J-C, Kuo H-C, Yu H-R, Wang C-L, Lee C-P, et al. Identification of an association between genomic hypomethylation of FCGR2A and susceptibility to Kawasaki disease and intravenous immunoglobulin resistance by DNA methylation array. Arthritis Rheumatol 2015;67:828-36. doi:10.1002/art.38976.

[121] Wang C, de Souza AWS, Westra J, Bijl M, Chen M, Zhao M-H, et al. Emerging role of high mobility group box 1 in ANCA-associated vasculitis. Autoimmun Rev 2015;14:1057-65. doi:10.1016/j.autrev.2015.07.010. 
Figure 1: Number of adult KD diagnoses by year

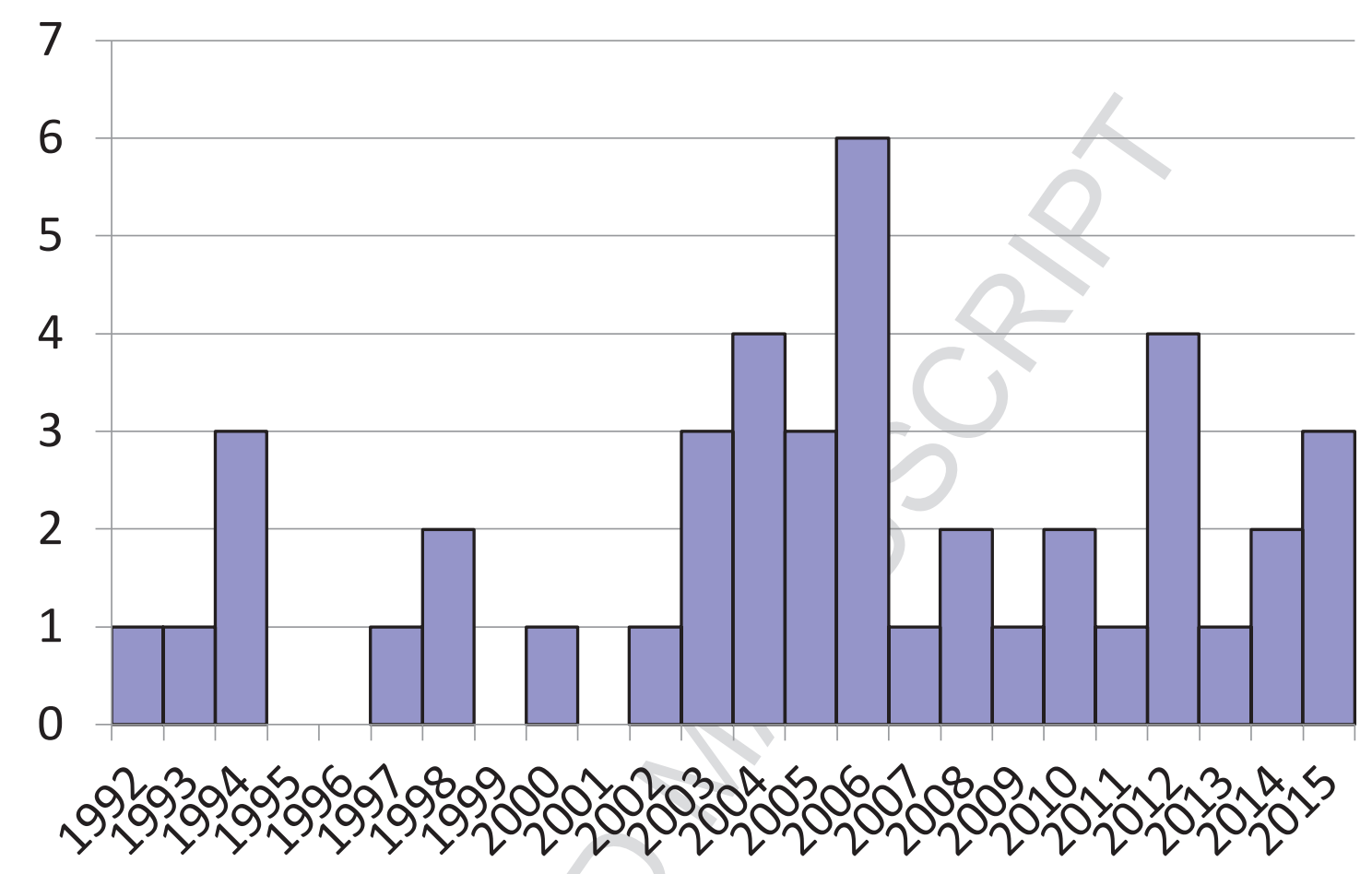

Figure 2: Seasonal distribution of adult KD cases

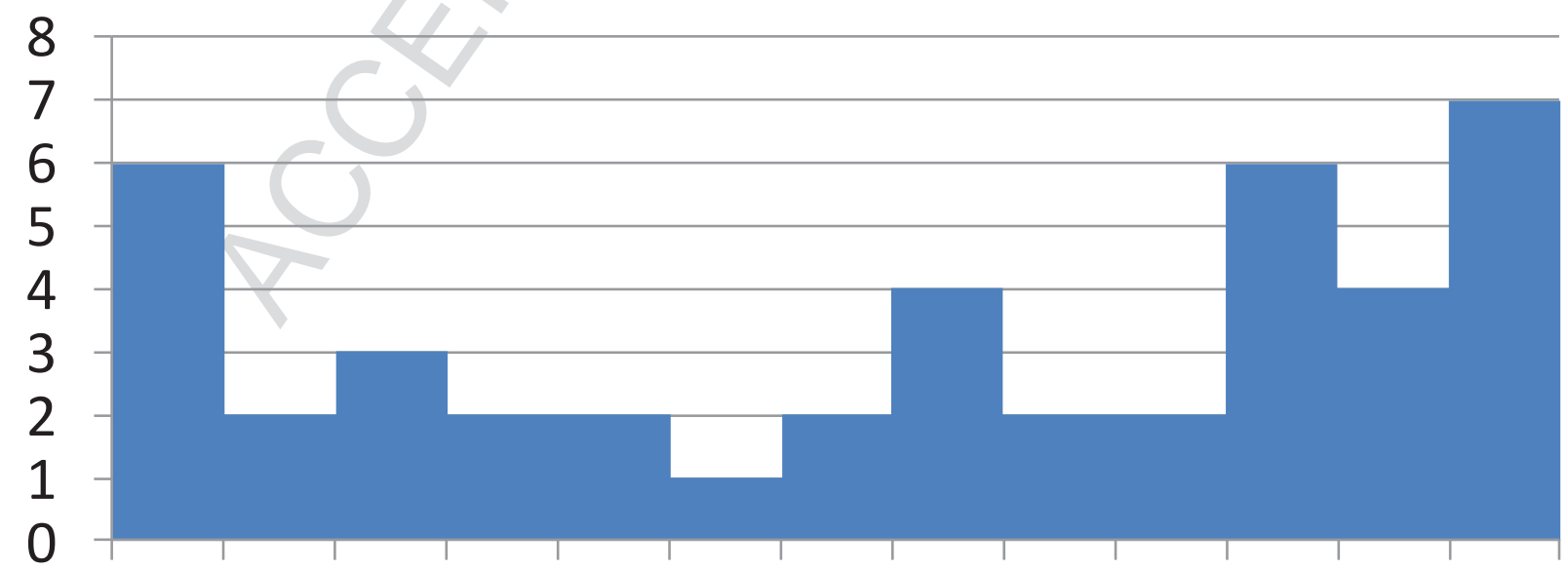

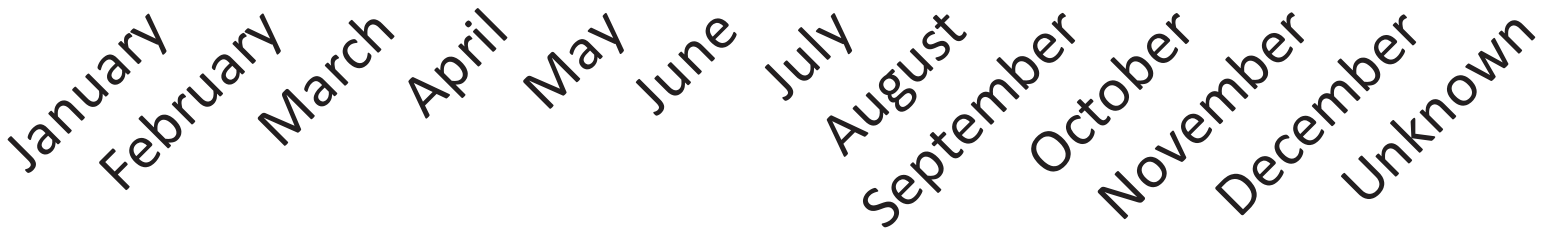




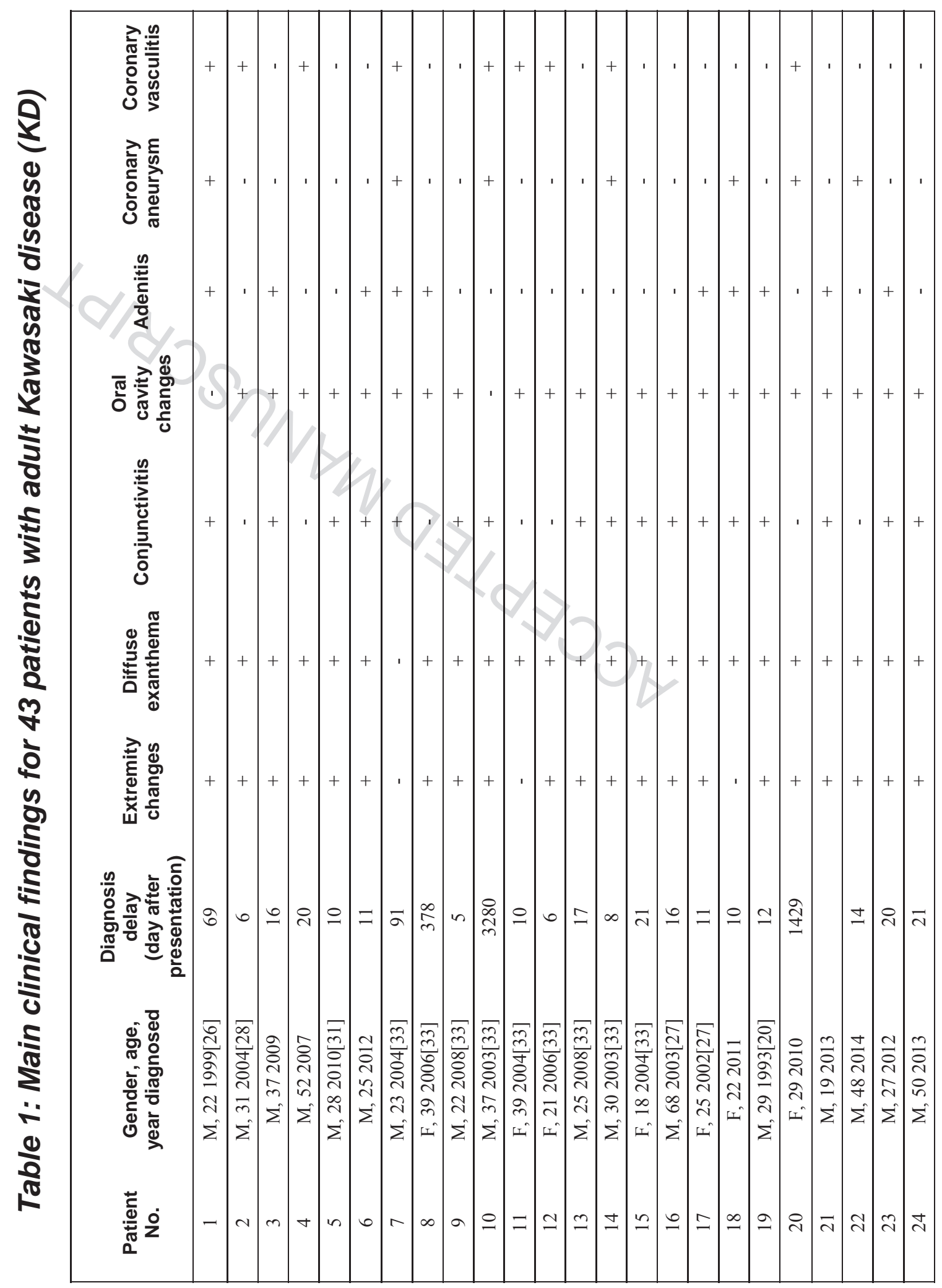




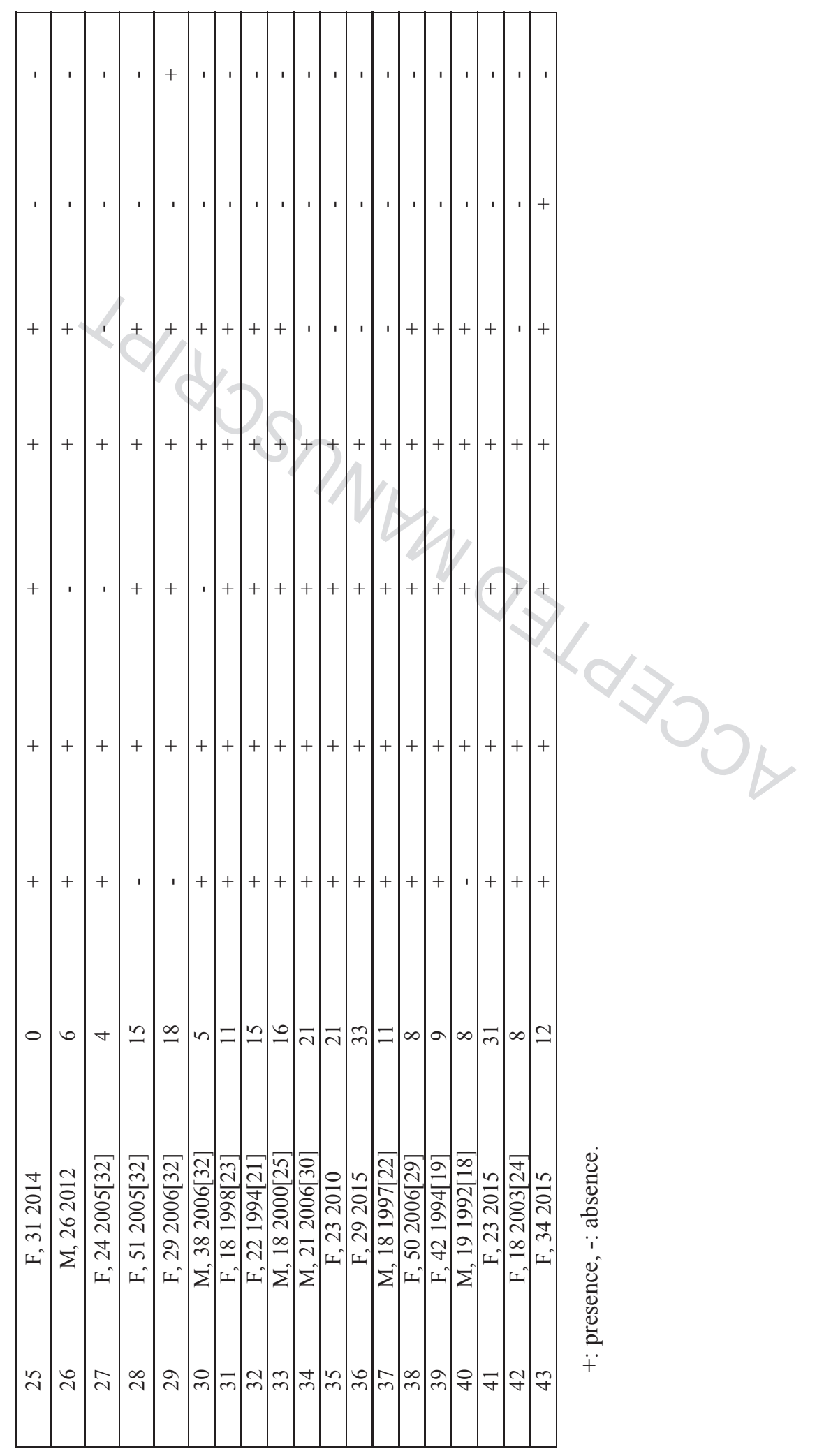


Table 2: Clinical findings for 43 patients with adult KD

\begin{tabular}{|c|c|}
\hline Clinical signs & $\begin{array}{l}\text { No. of cases } \\
(\%)\end{array}$ \\
\hline $\begin{array}{l}\text { General signs } \\
\text { Fever } \\
\text { Lymphadenopathy }\end{array}$ & $\begin{array}{l}43(100) \\
43(100) \\
24(56)\end{array}$ \\
\hline \begin{tabular}{|} 
Mucocutaneous signs \\
Extremities changes \\
Edema \\
Peeling \\
Diffuse exanthema \\
Oral cavity changes \\
Cheilitis \\
Strawberry tongue \\
Injected oral mucosa
\end{tabular} & $\begin{array}{l}43(100) \\
39(91) \\
26(61) \\
33(77) \\
42(98) \\
39(91) \\
31(72) \\
20(47) \\
26(61)\end{array}$ \\
\hline \begin{tabular}{|} 
Ocular involvement \\
Conjunctivitis \\
Anterior uveitis \\
Posterior uveitis \\
Scleritis
\end{tabular} & $\begin{array}{l}35(81) \\
35(81) \\
3(7) \\
1(2) \\
3(7)\end{array}$ \\
\hline $\begin{array}{l}\text { Cardiac signs } \\
\text { Chest pain } \\
\text { Cardiac shock } \\
\text { Left heart failure } \\
\text { Right heart failure } \\
\text { Myocardial infarction }\end{array}$ & $\begin{array}{l}19(44) \\
10(23) \\
2(5) \\
4(9) \\
2(5) \\
4(9)\end{array}$ \\
\hline $\begin{array}{c}\text { Rheumatologic involvement } \\
\text { Joint pain } \\
\text { Myalgia }\end{array}$ & $\begin{array}{l}22(51) \\
18(42) \\
14(33)\end{array}$ \\
\hline $\begin{array}{l}\text { Gastrointestinal involvement } \\
\text { Abdominal pain } \\
\text { Diarrhea } \\
\text { Jaundice } \\
\text { Emesis } \\
\text { Hepatomegaly } \\
\text { Splenomegaly }\end{array}$ & $\begin{array}{l}24(56) \\
11(26) \\
5(12) \\
10(23) \\
6(14) \\
6(14) \\
5(12)\end{array}$ \\
\hline \begin{tabular}{|l} 
Neurological involvement \\
Headache \\
Confusion \\
Aseptic meningitis \\
Hearing loss \\
Dizziness
\end{tabular} & $\begin{array}{l}10(23) \\
11(26) \\
2(5) \\
3(7) \\
2(5) \\
2(5)\end{array}$ \\
\hline
\end{tabular}




\section{Table 3: Biological findings for 43 patients with adult KD}

\begin{tabular}{|c|c|}
\hline Hematology & $\begin{array}{l}\text { Platelets }(\mathrm{n}=33): 358 \mathrm{~g} / \mathrm{L}(210-656) \\
\text { WBC }(\mathrm{n}=38): 15 \mathrm{G} / \mathrm{L}(9.3-20.8) \\
\text { Neutrophils }(\mathrm{n}=32): 14 \mathrm{~g} / \mathrm{L}(9.7-18) \text {, } \\
\text { Eosinophils }(\mathrm{n}=14) 0.7 \mathrm{~g} / \mathrm{L}(0.3-1.6) \text {, hypereosinophilia }(\mathrm{n}=7) \\
\text { Hemoglobin }(\mathrm{n}=23): 12 \mathrm{~g} / \mathrm{dL}(11.2-13.6)\end{array}$ \\
\hline Biochemistry & $\begin{array}{l}\text { CRP }(n=38): 205 \mathrm{mg} / \mathrm{L}(104-298), \\
\text { ESR }(\mathrm{n}=19): 70 \mathrm{~mm}(48-90) \\
\text { Fibrinogen }(\mathrm{n}=19): 7.9 \mathrm{~g} / \mathrm{L}(6.1-10.3) \\
\text { Ferritin }(\mathrm{n}=10): 840 \mu \mathrm{g} / \mathrm{L}(240-1327) \\
\text { Procalcitonin }(\mathrm{n}=10): 1.4 \mu \mathrm{g} / \mathrm{L}(0.04-6.4) \\
\text { SGOT }(\mathrm{n}=33): 71 \mathrm{IU} / \mathrm{L}(45-130), \\
\text { SGPT }(\mathrm{n}=34): 109 \mathrm{IU} / \mathrm{L}(58-185) \text {, hepatic cytolysis }(\mathrm{n}=23) \\
\text { Total bilirubin }(\mathrm{n}=20): 30 \mu \mathrm{g} / \mathrm{L}(\mathrm{IQ} 17-69) \text {, elevation }(\mathrm{n}=10) \\
\text { Troponin }(\mathrm{n}=18): 0.47 \mathrm{ng} / \mathrm{mL}(0.26-0.8), \text { elevation }(\mathrm{n}=9) \\
\text { Natremia }(\mathrm{n}=19): 133 \mathrm{mmol} / \mathrm{L}(130-137), \text { hyponatremia }(\mathrm{n}=9) \\
\text { Creatininemia }(\mathrm{n}=18): 67 \mu \mathrm{mol} / \mathrm{L}(60-84) \\
\text { Albuminemia }(\mathrm{n}=12): 28 \mathrm{~g} / \mathrm{L}(22-32)\end{array}$ \\
\hline Infectiology & 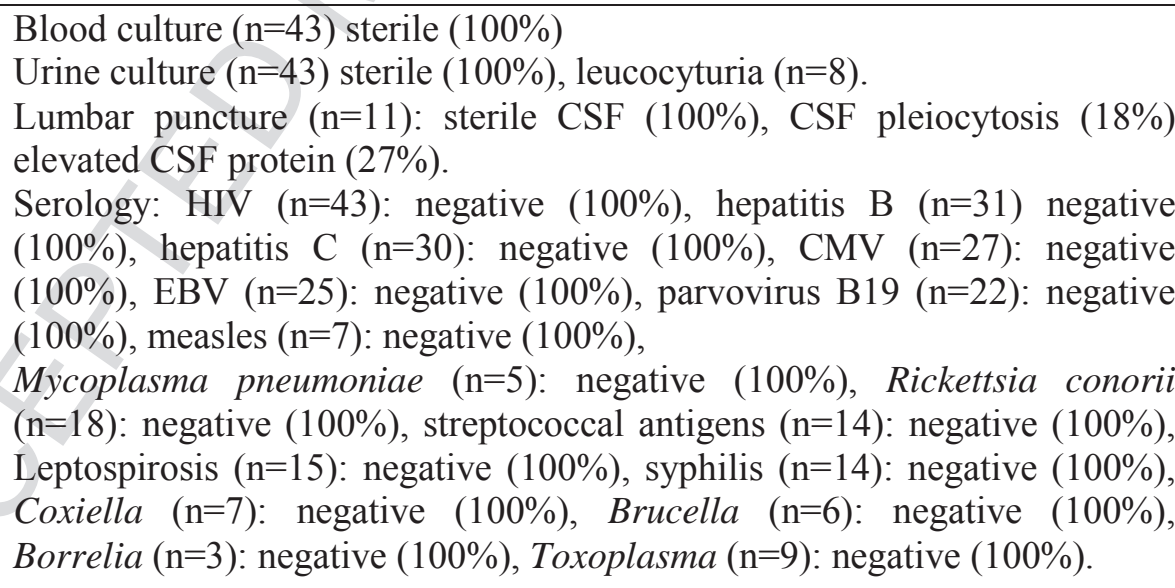 \\
\hline Immunology & $\begin{array}{l}\text { Anti-nuclear antibodies }(\mathrm{n}=24) \text { : negative }(100 \%) \\
\text { Anti-DNA antibodies }(\mathrm{n}=17) \text { : negative }(100 \%), \\
\text { Nuclear specificity }(\mathrm{n}=16) \text { : negative }(100 \%) \text {, } \\
\text { Anti-neutrophil cytoplasmic antibodies }(\mathrm{n}=20) \text { : negative }(100 \%) \\
\text { Circulating anticoagulant }(\mathrm{n}=5) \text { : negative }(100 \%) \\
\text { Anti-B2GP1 antibodies }(\mathrm{n}=5) \text { : negative }(100 \%) \\
\text { Anticardiolipin antibodies }(\mathrm{n}=6) \text { : positive } \quad(16 \%) \text {, negative } \quad(84 \%) \\
\text { Cryoglobulin }(\mathrm{n}=8) \text { : negative }(100 \%)\end{array}$ \\
\hline
\end{tabular}

Data are no. of available results: median (interquartile range)

WBC: white blood cells, CRP: C-reactive protein, ESR: erythrocyte sedimentation rate, SGOT: serum glutamate-oxaloacetate transaminase, SGPT: serum glutamic-pyruvic transaminase, CMV: cytomegalovirus, EBV: Epstein-Barr virus 
Table 4: Early treatment (before day 9 after presentation) versus late or no treatment in 43 patients with $K D$

\begin{tabular}{|c|c|c|c|}
\hline Characteristics & $\begin{array}{c}\text { Early treatment } \\
(\mathrm{n}=12)\end{array}$ & $\begin{array}{c}\text { Late or no treatment } \\
(\mathrm{n}=31)\end{array}$ & P value \\
\hline Age (years), median (range) & $28(18-50)$ & $27(18-68)$ & 0.98 \\
\hline M/F ratio & 1 & 1.2 & 1 \\
\hline Smoking & $3 / 12(25)$ & $8 / 31(26)$ & 1 \\
\hline Cardiovascular disease risk factor & $3 / 12(25)$ & $10 / 31(32)$ & 0.72 \\
\hline Fever duration (days), median (range) & $\mathbf{1 0 ( 4 - 1 2 )}$ & $\mathbf{1 6}(5-64)$ & $\mathbf{0 . 0 0 2 *}$ \\
\hline Peeling delay (days), median (range) & $11(2-27)$ & $15(4-45)$ & 0.07 \\
\hline Apyrexia delay after IVIg (days), \\
median (range) & $2(1-4)$ & $1.5(0-4)$ & 0.07 \\
\hline Cardiac screening limited to & $8 / 12(67)$ & $11 / 31(35)$ & 0.09 \\
\hline echocardiography & $8 / 12(67)$ & $16 / 31(52)$ & 0.50 \\
\hline Initial abnormal echocardiography & $0 / 12(0)$ & $4 / 31(13)$ & 0.56 \\
\hline Myocardial infarction & $3 / 12(25)$ & $8 / 31(26)$ & 1 \\
\hline Pericarditis & $1 / 12(8)$ & $5 / 31(16)$ & 0.65 \\
\hline Myocarditis & $4 / 12(33)$ & $11 / 31(35)$ & 1 \\
\hline Large-vessel vasculitis & $1 / 12(8)$ & $7 / 31(23)$ & 0.40 \\
\hline Coronary aneurysm & $4 / 12(33)$ & $7 / 31(23)$ & 0.47 \\
\hline Coronary vasculitis & $\mathbf{1 0 / 1 2 ( 8 3 )}$ & $\mathbf{1 4 / 3 1 ( 4 5 )}$ & $\mathbf{0 . 0 4 *}$ \\
\hline Anti-inflammatory dose of aspirin & $\mathbf{4 ( 3 - 1 3 )}$ & $\mathbf{9 ( 3 - 1 8 )}$ & $\mathbf{0 . 0 0 6 *}$ \\
\hline Initial BVAS, median (range) & $\mathbf{0 ( 0 - 1 )}$ & $\mathbf{0 ( 0 - 6 )}$ & $\mathbf{0 . 0 1 *}$ \\
\hline VDI, median (range) & $5(1-110)$ & $5(1-117)$ & 0.87 \\
\hline Follow-up (months), median (range) & & & \\
\hline
\end{tabular}

Data are no. (\%) unless indicated.

IVIg: intravenous immunoglobulins, BVAS: Birmingham Vasculitis Activity Score, VDI: Vasculitis Damage Index 